\title{
PEMBERHENTIAN KEPALA DAERAH KARENA MELAKUKAN TINDAK PIDANA KORUPSI MENURUT UNDANG-UNDANG HUKUM ISLAM
}

\author{
Wery Gusmansyah \\ Dosen Syariah IAIN Bengkulu \\ Jalan Raden Fatah Pagar Dewa Bengkulu \\ Email: Wery_Gusmansyah@yahoo.com
}

\begin{abstract}
The process of dismissal according to the Act is without going through the proposal of the DPRD and being tried directly by the Corruption Court. When the file has been submitted to the court a temporary stop will be applied. After obtaining a permanent decision (inkracht), if proven to be innocent then no later than 30 days the Regional Head concerned will be reactivated. If proven guilty the President dismisses the Governor and / or Deputy Governor and the Minister dismissing the Regent and / or Deputy Regent and Mayor and / or Deputy Mayor. The case of corruption that is authorized to prosecute in Islamic law is the Mazhalim Court to decide on the case (verdict / verdict). Then the Amir was given 10 days after the ruling was issued to defend the charges. If the plea is rejected, then he is immediately dismissed if at least two-thirds of the members of Majelis al-Shura are present at the special session to carry out the dismissal. Furthermore, the authority to dismiss the Regional Head is the Caliph. In general, the mechanism of dismissal of Regional Heads has many differences but there are several aspects of equality such as the President / Caliph who has the authority to dismiss the Regional Head.
\end{abstract}

Keywords: Dismissal, Regional Head, Corruption Crime, Islamic Law.

\begin{abstract}
Abstrak: Proses pemberhentian menurut Undang-Undang adalah tanpa melalui usul DPRD dan diadili langsung oleh Pengadilan Tipikor. Saat berkas telah dilimpahkan ke pengadilan maka akan diberlakukan pemberhentian sementara. Setelah memperoleh putusan yang tetap (inkracht), jika terbukti tidak bersalah maka paling lambat 30 hari Kepala Daerah bersangkutan akan diaktifkan kembali. Apabila terbukti bersalah Presiden memberhentikan Gubernur dan/atau Wakil Gubernur dan Menteri memberhentikan Bupati dan/atau Wakil Bupati dan Walikota dan/atau Wakil Walikota. Perkara tindak pidana korupsi yang berwenang mengadili dalam hukum Islam adalah Mahkamah Mazhalim untuk menjatuhkan keputusan terhadap perkara tersebut (putusan/vonis). Kemudian Amir tersebut diberi waktu 10 hari sejak putusan dikeluarkan untuk memberikan pembelaan atas tuduhan-tuduhan. Jika pledoinya ditolak, maka ia segera dipecat bila sekurang-kurangnya 2/3 anggota Majelis al-Syura yang hadir dalam sidang istimewa untuk melakukan pemberhentian Selanjutnya yang berwenang memberhentikan Kepala Daerah tersebut adalah Khalifah. Secara umum, mekanisme pemberhentian Kepala Daerah memiliki banyak perbedaan namun ada bebarapa aspek persamaan seperti Presiden/Khalifah yang berwenang memberhentikan Kepala Daerah tersebut.
\end{abstract}

Kata Kunci :Pemberhentian, Kepala Daerah, Tindak Pidana Korupsi, Hukum Islam. 
Wery Gusmansyah: Pemberhentian Kepala Daerah Karena Melakukan Tindak Pidana Korupsi Menurut Undang-Undang Hukum Islam

\section{Pendahuluan}

Indonesia merupakan

negara

demokrasi. Prinsip dasar negara demokrasi selalu menuntut dan mengharuskan adanya pemecahan kekuasaan, agar kekuasaan tak terpusat di satu tangan. Kekuasaan yang berada di satu tangan bertentangan dengan prinsip demokrasi karena ia membuka peluang terjadinya kesewenangan dan korupsi. Dalil umum yang terkenal tentang ini adalah pernyataan Lord Acton bahwa "Powertends to corrupt and absolute power corrupts absolutely" (kekuasaan itu cenderung korup dan kekuasaan absolut -terpusat -korup secara absolut). ${ }^{1}$

Sejak reformasi 1998, titik penyelenggaraan pemerintahan bergeser dari pusat ke daerah. Pergeseran ini diatur dalam beberapa Undang-Undanag seperti, UndangUndang Nomor 1 Tahun 1945 tentang Otonomi Daerah, Undang-Undang Nomor 22 Tahun 1948, Undang-Undang Nomor 1 Tahun 1957, Peraturan Presiden No 6 Tahun 1959, TAP MPRS No.XXI/MPRS/1966, UndangUndang No 5 Tahun 1974, Undang-Undang No 22 Tahun 1999, Undang-Undang Nomor 32 Tahun 2004, Undang-Undang Nomor 23 Tahun 2014, dan terakhir Undamg-Undang No 9 Tahun 2015. Secara substansial UndangUndang tersebut mengatur tentang bentuk susunan penyelenggaraan daerah. Secara normatif undang-undang tersebut telah mampu

1 Mahfud MD, Membangun Politik Hukum Menegakkan Konstitusi, (Jakarta: Rajwali Press, 2012), h. 215 mengikuti perkembangan perubahan pemerintah daerah sesuai zamannya. $^{2}$

Pemerintahan daerah merupakan penyelenggaraaan urusan pemerintah oleh Pemerintah Daerah dan Dewan Perwakilan Rakyat Daerah (DPRD) menurut asas otonomi dan tugas pembantuan dengan prinsip seluasluasnya dalam sistem dan prinsip Negara Kesatuan Republik Indonesia sebagaimana dimaksud dalam Undang-Undang Dasar Negara Republik Indonesia Tahun 1945. Kepala daerah sebagai unsur penyelenggaran Pemerintahan Daerah yang memimpin pelaksanaan urusan pemerintahan yang menjadi kewenangan daerah otonom. ${ }^{3}$

Kepala daerah adalah pejabat yang menjalankan hak wewenang dan kewajiban pimpinan pemerintahan daerah atau pejabat yang memimpin disuatu daerah tertentu dan bertanggung jawab sepenuhnya atas jalannya pemerintahan daerah. ${ }^{4}$ Kepala Daerah meliputi Gubernur untuk Provinsi, Bupati untuk Kabupaten, serta Walikota untuk Kota. Menurut fiqh siyasah kepala daerah disebut wali. Wali adalah orang yang didangkat khalifah untuk menjadi pejabat pemerintahan (hakim) di suatu daerah serta menjadi pemimpin di daerah tertentu. ${ }^{5}$ Kepala daerah

${ }^{2}$ Siswanto Sunarno, Hukum Pemerintahan Daerah di Indonesia, (Jakarta: Sinar Grafika, 2006), h.54.

${ }^{3}$ Andi Mustari Pide, Otonomi Daerah Dan Kepala Daerah Memasuki Abad XXI, (Jakarta: Radar Raya Pratama, 1999), h. 23.

${ }^{4}$ Andi Mustari Pide, Otonomi Daerah Dan Kepala Daerah Memasuki Abad XXI..., h 50-51

${ }^{5}$ Taqiyuddi An Nabhani, Sistem Pemrintahan Islam:Dokttrin Sejarah dan Realitas Empiris, h. 29 
AL-IMARAH: Jurnal Pemerintahan dan Politik Islam Vol. 3, No. 1, 2018

secara hierarki tidak jauh berbeda dengan kedudukan presiden yang penanggung jawab tertinggi dalam penyelenggaraan diseluruh wilayah. Sedangkan kepala daerah hanya bertanggungjawab di wilayah tertentu yang dipimpinnya.

Islampun menjelaskan bahwa kepala daerah dikenal dengan sebutan "Amir". Istilah amir digunakan untuk gelar-gelar jabatan penting yang bervariasi dalam perkembangan sejarah pemerintahan islam dengan sebutan yang beragam seperti amir al-mu'minin, amir al-muslimin, amir al-umara, dan amir saja. Karena itu bisa digunakan untuk gelar kepala pemerintahan di daerah dan gelar untuk penguasa militer. ${ }^{6}$

Korupsi adalah tingkah laku yang menyimpang dari tugas-tugas resmi sebuah jabatan negara karena keuntungan status atau uang yang menyangkut pribadi (perorangan, keluarga dekat, kelompok sendiri) atau melanggar aturan-aturan pelaksanaan beberapa tingkah laku pribadi. $^{7}$ Adapun menurut Undang-Undang Republik Indonesia Nomor 31 Tahun 1999 tentang Pemberantasan Tindak Pidana Korupsi yang dimaksud dengan korupsi adalah secara melawan hukum melakukan perbuatan memperkaya diri sendiri atau orang lain atau suatu korporasi yang dapat

\footnotetext{
${ }^{6}$ Suyuti Pulungan, Fiqh Siyasah:ajaran, sejarah, dan pemikiran, (Jakarta: PT Raja Grafindo Persada 1994), h. 63.

${ }^{7}$ Robert Klitgaard, Membassmi Korupsi ,Cet-.II, (Jakarta: Yayasan Obor Indonesia ,2001), h.31.
}

merugikan keuangan negara atau perekonomian negara. ${ }^{8}$

Dalam khazanah hukum islam, prilaku korupsi belum memperoleh porsi pembahasan yang memadai, ketika para Fuqaha berbicara tentang kejahatan memakan harta benda manusia secara tidak benar (akl amwal al-nas bi al-batil) seperti yang diharamkan dalam AlQur'an, tetapi apabila merujuk kepada kata asal dari korupsi, maka dapat berarti merusak (dalam bentuk kecurangan) atau menyuap. Ayat dalam Al-Qur'an yang berkaitan dengan Korupsi yaitu Q.S al-Baqarah ayat 188:

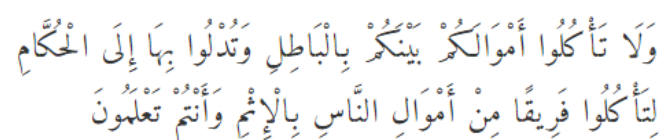

Artinya:

Dan janganlah sebagian kamu memakan harta sebagian yang lain diantara kamu dengan jalamn yang bathil dan (janganlah) kamu membawa (urusan)harta itu kepada hakim, supaya kamu dapat memakan sebagian daripada harta benda orang lain itu dengan (jlan berbuat) dosa, padahal kamu mengetahui.

Menurut tafsir dari quraish shihab bahwa diharamkan atas kalian memakan harta orang lain secara tidak benar. Harta orang lain itu tidaklah halal bagi kalian kecuali jika diperoleh melalui cara-cara yang ditentukan Allah seperti pewarisan, hibah dan transaksi yang sah dan dibolehkan. Terkadang ada orang

\footnotetext{
${ }^{8}$ Undang-Undang RI Nomor 31 Tahun 1999 Pemberantasan Tindak Pidana Korupsi
} 
yang menggugat harta saudaranya secara tidak benar. Untuk mendapatkan harta saudaranya itu, ia menggugat di hadapan hakim dengan memberi saksi dan bukti yang tidak benar, atau dengan memberi sogokan yang keji. Perlakuan seperti ini merupakan perlakuan yang sangat buruk yang akan dibalas dengan balasan yang buruk pula. Ayat ini mengisyaratkan bahwa praktek sogok atau suap merupakan salah satu tindak kriminal yang paling berbahaya bagi suatu bangsa. Pada ayat tersebut dijelaskan pihak-pihak yang melakukan tindakan penyuapan. Yang pertama, pihak penyuap, dan yang kedua, pihak yang menerima suap, yaitu penguasa yang menyalahgunakan wewenangnya dengan memberikan kepada pihak penyuap sesuatu yang bukan haknya.

Dalam konteks ajaran Islam yang lebih luas, korupsi merupakan tindakan yang bertentangan dengan prinsip keadilan ( $a l$ - 'adl), akuntabilitas (al-amanah), dan tanggung jawab. Korupsi dengan segala dampak negatifnya yang menimbulkan berbagai distorsi terhadap kehidupan negara dan masyarakat dapat dikategorikan termasuk perbuatan fasad, kerusakan dimuka bumi, yang juga amat dikutuk Allah SWT.

Meskipun terdapat berbagai rumusan tentang apa itu korupsi, namun esensinya selalu berkaitan dengan penyalahgunaan kekuasaan atau wewenang untuk memperoleh keuntungan atau manfaat, baik bagi kepentingan diri sendiri, keluarga, orang lain atau suatu badan tertentu. Perilaku korup dapat terjadi dalam berbagai bentuk dan pariasinya serta berbagai modus aperandi. Mulai dari bentuk-bentuk korupsi yang sangat sederhana sampai pada bentuk-bentuk yang canggih dan rumit pembuktiannya. Paling sedikit ada empat kategori perbuatan yang dapat digolongkan ke dalam konsep yuridis tentang korupsi, yaitu: ${ }^{9}$
a. Suap menyuap (Beribery)
b. Pemerasan (Extortion)
c. Penipuan/penggelapan (Fraud)
d. Nepotisme (Nepotism)

Kasus-kasus korupsi yang menjangkit di kalangan Kepala Daerah terus bertambah. Persoalan kedudukan Kepala Daerah yang terjerat korupsi masih meninggalkan masalah pemberhentian kepala daerah yang tidak melalui prosedur yang diatur dalam UndangUndang Nomor 23 Tahun 2014 tentang Pemerintahan Daerah. Pemberhentian secara sementara dalam Undang-Undang pemerintahan daerah tidak mengatur ketika status kepala daerah yang berstatus tersangka dapat diberhentikan. Pengaturan lebih lanjut kepala daerah berstatus terdakwa seharusnya bisa diberhentikan secara sementara melalui ketentuan yang diatur secara jelas dalam Pasal 83 ayat (1) kepala daerah dan/atau wakil kepala daerah diberhentikan sementara tanpa melalui usulan DPRD karena didakwa melakukan tindak pidana kejahatan yang diancam pidana penjara paling singkat 5 tahun, tindak pidana korupsi, tindak pidana terorisme,

${ }^{9}$ Haji Elwi Daniel, Korupsi : Konsep,Tindak Pidana dan Pemberatasannya, (Jakarta: Rajawali Pers, 2012), h. 178. 
AL-IMARAH: Jurnal Pemerintahan dan Politik Islam Vol. 3, No. 1, 2018

makar, tindak pidana terhadap keamanan negara, dan/atau perbuatan lain yang dapat memecah belah Kesatuan Negara Republik Indonesia.

\section{Pembahasan}

Dalam Pasal 127 Peraturan Pemerintah Nomor 6 Tahun 2005 tentang Pemilihan, Pengesahan Pengangkatan dan Pemberhentian Kepala Daerah yang menyebutkan bahwa:

1. Kepala Daerah dan/atau Wakil Kepala Daerah diberehentikan tanpa melalui usulan DPRD, karena terbukti malakukan tindak pidana korupsi,terorisme,makar dan/atau tindak pidana terhadap keamanan Negara yang dinyatakan dengan putusan pengadilan yang telah mempunyai kekuatan hukum tetap.

2. Presiden memperoses pemberhentian berdasarkan putusan pengadilan yang telah mempunyai kekuatan hukum tetap yang menyatakan Gubernur dan/atau Wakil Gubernur terbukti melakukan tindak pidana korupsi,terorisme,makar dan/atau tindak pidana terhadap keamanan negara, melalui usulan Menteri Dalam Negeri

3. Menteri Dalam Negeri memperoses pemberhentian sebagaimana dimaksud pada ayat (1), berdasarkan Putusan Penagadilan yang telaha mempunyai kekuatan hukum tetap yang menyatakan Bupati dan /atau Wakil
Bupati atau Walikota dan/atau Wakil Walikota terbukti melakukan tindak pidana korupsi, terorisme, maker dan/atau tindak pidana terhadap keamanan negara, melalui usulan Gubernur.

Kepala daerah diberhentikan sementara oleh Presiden tanpa melalui usulan DPRD, apabila didakwa karena melakukan tindak pidana kejahatan yang diancam dengan pidana penjara paling singakat 5 (lima) tahun dalam hal ini tindak pidana korupsi berdasarkan register perkara pengadilan.. Proses pemberhentian sementara Kepala Daerah, dilakukan apabila berkas perkara dakwaan melakukan tindak pidana korupsi telah dilimpahkan ke pengadilan dan dalam proses penututan dengan dibuktikan register perkara. Berdasarkan bukti register perkara Presiden memberhentikan sementara kepala daerah melalui usulan Menteri Dalam Negeri. Apabila Kepala Daerah telah diberhentikan sementara maka wakil kepala daerah melaksanakan tugas dan kewenangan kepala daerah sampai dengan adanya putusan pengadilan yang telah memperoleh kekuatan hukum tetap.

Namun, apabila ternyata setelah melalui proses peradilan kepala daerah dan/atau wakil kepala daerah yang diberhentikan sementara itu terbukti tidak bersalah berdasarkan putusan pengadilan, maka paling lambat 30 hari terhitung sejak diterimanya pemberitahuan putusan pengadilan, Presiden mengaktifkan kembali 
Wery Gusmansyah:

Pemberhentian Kepala Daerah Karena Melakukan Tindak Pidana Korupsi Menurut Undang-Undang Hukum Islam

gubernur dan/atau wakil gubernur yang bersangkutan, dan Menteri mengaktifkan kembali bupati dan/atau wakil bupati atau wali kota dan/atau wakil wali kota yang bersangkutan. Kemudian apabila setelah diaktifkan kembali, kepala daerah dan/atau wakil kepala daerah yang terbukti tidak bersalah berdasarkan putusan pengadilan yang telah memperoleh kekuatan hukum yang tetap, Presiden merehabilitasi Gubernur dan/atau Wakil Gubernur, dan menteri merehabilitasi Bupati dan/atau Wakil Bupati. Maksud dari merehabilitasi dalam ayat tersbut yaitu pemulihan nama baik dan pemenuhan hak keuangan.

Sedangkan dalam ketentuan Pasal 83 jika kepala daerah yang statusnya dihukum (terhukum) atau terpidana membawa konsekuensi dicabutnya secara demi hukum jabatan kepala daerah yang diembannya dan kondisi inilah yang kemudian mengaktifkan ketentuan Pasal 78 ayat (1.c) sehingga mewajibkan presiden mengeluarkan keputusan pemberhentian, karena seorang yang terhukum atau terpidana adalah suatu keadaan yang melanggar sumpah, dianggap sesuatu yang tercela dan yang diberi sanksi pemberhentian. Maka pemberhentian dilaksanakan langsung oleh Presiden untuk Gubernur dan/atau Wakil Gubernur, sedangkan untuk Bupati dan/atau Wakil Bupati atau Wali Kota dan/atau Wakil Wali Kota dilaksanakan langsung oleh Mendagri (Menteri dalam negeri).
2. Pemberhentian Kepala Daerah Karena Melakukan Tindak Pidana Korupsi

\section{Menurut Hukum Islam}

Istilah pemberhentian dipadankan juga dengan istilah pemakzulan yang mempunyai konotasi yang sama dengan istilah impeachment. Menurut istilah pemakzulan adalah tindakan politik dengan hukuman berhenti dari jabatan dan kemungkinan larangan untuk memegang suatu jabatan, bukan sebagai hukuman pidana (criminal convection) atau pengenaan ganti kerugian. Dalam istilah akademik, pemakzulan adalah proses hukum ketatanegaraan untuk memecat presiden atau pejabat lainnya dari jabatannya. $^{10}$

Kepemimpinan dalam pandangan islam merupakan amanah dan tanggung jawab yang tidak hanya dipertanggungjawabkan kepada anggotaanggota yang dipimpin saja, akan tetapi juga akan dipertanggungjawabkan di hadapan Allah SWT. Tanggung jawab pemimpin terhadap rakyat tentu kita harus ukur berdasarkan petunjuk dan ketentuan yang diberikan Allah SWT yang dibawa oleh Rasulullah SAW. Asy-syar'i telah menentukan tanggung jawab pemimpin terhadap rakyat pada semua level, termasuk kepada level kepala negara. Islam sebagai agama yang berorientasi

10 Hamdan Zoelva, Impeachment Presiden Alasan Tindak Pidana Pemberhentian Presiden Menurut UU 1945, (Jakarta: Sinar Grafika, 2011), h.10. 
kepada perwujudan kemashlahatan umat manusia yang menginginkan mereka hidup berbahagia di dunia dan akhirat. ${ }^{11}$

Konsep kepemimpinan dalam islam dikenal juga dengan istilah wali. Wali adalah orang yang diangkat oleh khalifah untuk menjadi pejabat pemerintahan (hakim) di suatu daerah serta pimpinan di daerah tersebut. Adapun negeri yang dipimpin oleh negara islam bisa diklasifikasikan menjadi beberapa bagian. Masing-masing bagian itu disebut wilayah (setingkat provinsi). Setiap wilayah dibagi menjadi beberapa bagian lagi dimana masing-masig bagian itu disebut imalah (setingkat kabupaten). Orang yang memimpin wilayah tersebut disebut wali. Sedangkan orang yang memimpin 'imalah disebut 'amil dan hakim. $^{12}$

Jabatan wali tersebut harus diserahkan oleh Khalifah atau orang yang mewakilinya dalam melakukan serah terima jabatan tersebut. Sehingga wali hanya bisa diangkat secara sah kalau yang melakukan serah-terima tersebut adalah khalifah. Adanya jabatan wali atau amir (kepemimpian) itu berdasarkan perbuatan Rasulullah SAW. Karena Rasulullah pernah mengangkat para wali untuk memimpin beberapa wilayah (daerah).

11 Azyumardi Azra, kajian Termasuk AlQur'an Tentang Kemasyarakatan, (Bandung: Angkatan, 2008), h.200

${ }^{12}$ Abdul Qadim Zallum,Sistem Pemerintahan Islam(Nidhamul Hukmi Fil Islam..., h.209
Mereka diberi wewenang untuk memimpin daerah-daerah tersebut. Beliau pernah mengangkat Mu'adz bin Jabal menjadi gubernur di Yaman. Sedangkan Ziyad bin Ladid di Hadramaut, dan Abu Musa alAsy'ari di Zabid dan 'Adn. ${ }^{13}$

Seorang wali adalah wakil khalifah dalam pemerintahan, sehingga wali juga merupakan seorang pejabat. Karena itu, untuk menjadi wali syaratnya sama seperti khalifah atau kepala negara. Menurut Imam Al-Mawardi ada tujuh syarat yang harus dimiliki untk menjadi kepala negara yaitu:

1. Adil dengan syarat-syaratnya yang universal

2. Ilmu yang membuatnya mampu berijtihad terhadap kasus-kasus dan hukum-hukum

3. Sehat indrawi (telinga, mata, dan mulut) yang dengannya mampu menangani langsung permasalahan yang telah diketahinya

4. Sehat organ tubuh dari cacat yang menghalanginya bertindak sempurna dan cepat

5. Wawasan yang luas yang membuatnya mampu memimpin rakyat dan mengelola semua kepentingan

6. Berani, dan ksatria yang membuatnya mampu melindungi wilayah negara dan melawan musuh

${ }^{13}$ Abdul Qadim Zallum,Sistem Pemerintahan Islam(Nidhamul Hukmi Fil Islam..., h.210 
7. Nasab yang berasal dari quraisy. ${ }^{14}$

Secara garis besar wali digolongkan menjadi dua, yaitu wali dengan wewenang umum dan wali dengan wewenang khusus. Wali dengan wewenang umum mengurusi semua urusan pemerintahan dan mengarahkan tugastugas instantsi yang ada di daerahnya untuk mewakili Khalifah. Dia mempunyai wewenang memimpin semua masyarakat yang ada di daerahnya, mengurusi semua urusan kecuali urusan harta, peradilan dan militer, dia berhak membuat kebijakan dalam masalah yang berhubungan dengan wilayah kekuasaannya. Sedangkan wali dengan wewenang khusus memiliki wewenang terbatas seperti khusus mengurusi masalah pasukan atau rakyat atau melindungi benteng atau menjaga daerah serta negara tersebut dari hal-hal yang terlarang. Dia juga tidak berwenang untuk memutuskan hukum dan mungumpulkan zakat atau pun kharaj. ${ }^{15}$

Sejarah Islam menyebutkan bahwa telah terjadi pemberhentian kepala daerah terlepas disebabkan oleh korupsi atau bukan seperti Rasulullah SAW pernah mengangkat para wali dengan wewenang secara mutlak dalam masalah pemerintahan. Sementara diantara ada

14 Imam Al-Mawardi,Al-Ahkam AsSulthaniyyyah,wal-wilaayaatud-diniyh Terjemahan Abdul hayie,dkk, Hukum Tata Negara dan Kepemimpinan, (Jakarta : Darul Falah,2007),h.18.

15 Abdul Qadim Zallum,Sistem Pemerintahan Islam(Nidhamul Hukmi Fil Islam),(Bangil : AlIzzah,2002), h.210 yang diangkat dengan wewenang secara umum serta sebagian yang lain diangkat dengan wewenang tertentu atau khusus. Misalnya, Beliau mengangkat Mu'adz menjadi wali/gubernur di Yaman lalu beliau memberhentikannya. ${ }^{16}$ Kemudian Rasulullah juga pernah memberhentikan Ila' Al-Hadhrami yang menjadi amil di Bahrain, karena beliau mendapat pengaduan tetang 'Ila dari utusan Abdul Qais.

Pemberhentian kepala daerah telah ada sejak zaman Rasulullah, akan tetapi pemberhentian yang disebakan korupsi secara spesifik tidak dijelaskan. Namun yang mendekati pemberhentian Kepala Daerah terjadi pada masa pemerintahan Ali disebabkan Nepotisme. Kemudian mengenai mekanisme pemberhentian Kepala Daerah/amir/wali, dalam Islam tidak ditemukan penjelasan yang rinci terutama bagi kepala daerah yang melakukan tindak pidana korupsi. Akan tetapi dalam kitab-kitab fiqh siyasah setidaknya ditemukan beberapa cara atau mekanisme pemberhentian Kepala Daerah yang disamakan dengan pemberhentian kepala Negara. Karena kepala Negara dan kepala daerah sama-sama memiliki peranan penting dalam memimpin suatu wilayah, yang membedakannya adalah batas wilayah kekuasaan.

16 Abdul Qadim Zallum,Sistem Pemerintahan Islam(Nidhamul Hukmi Fil Islam)..., h.216 
Seperti yang dikemukan oleh Imam Al-Mawardi bahwa ada dua alasan yang membolehkan pemakzulan (impeachment) imam/khalifah/kepala negara. Pertama, karena ia mengalami perubahan dalam status moral (akhlak), secara teknis sebut saja pelanggaran terhadap norma-norma keadilan ('adalah). Kedua, kareana terjadi perubahan dalam diri imam itu sendiri. Dalam hal ini dibagi tiga hal yakni hilang panca indra jasmani, hilang/cacat organ tubuh, dan hilang kemampuan mengawasi dan memimpin rakyat. ${ }^{17}$

Sedangkan dalam pandangan alNabhani, pemecatan khalifah dibolehkan dengan beberapa alasan. Pertama, kalau khalifah murtad dari Islam. Islam bukan hanya menjadi syarat utama dalam pengangkatan sebagai Kepala Negara akan tetapi sekaligus sebagai syarat untuk bisa terus memegang jabatan sebagai khalifah. Oleh sebab itu, seorang kepal negara yang murtad dalam islam wajib diberhentikan. ${ }^{18}$ Kedua, khalifah gila total (parah) yang tidak bisa disembuhkan. Ketiga, khalifah ditawan musuh yang kuat dan dia tidak mungkin bisa lagi melepaskan diri dari tawanan tersebut, bahkan tidak ada harapan untuk bisa bebas.

${ }^{17}$ Mujar Ibnu Syarif dan Khamami Zada, Fiqh Siyasah(Doktrin dan Pemikiran Politik Islam),(Jakarta : Erlangga, 2008), h.168-167

${ }^{18}$ Mujar Ibnu Syarif dan Khamami Zada, Fiqh Siyasah(Doktrin dan Pemikiran Politik Islam,...h.174
Kemudian alasan yang

membenarkan

pemakzulan

(impeachment) khalifah/imam/kepala negara menurut Din Syamsuddin antara lain: menyimpang dari keadilan, kehilangan panca indera atau organ tubuh yang lain, kehilangan kebebasan bertindak karaena telah dikuasai oleh orang-orang dekatnya, tertawan, atau menjadi fasik yaitu terjatuh ke dalam kecenderungan syahwat semisal melakukan perselingkuhan. ${ }^{19}$

Perilaku korupsi dikalangan pejabat negara merupakan perbuatan yang sangat zhalim yang menyalahgunaan jabatan untuk memperkaya diri sendiri atau orang lain adalah perbuatan mengkhianati amanah yang diberikan masyarakat kepadanya. karena kekayaan negara adalah harta yang dipungut dari masyarakat termasuk masyarakat miskin yang mereka peroleh dengan susah payah. Bahkan perbuatan tersebut berdampak sangat luas serta berdampak menambah kuantitas masyarakat miskin baru . Oleh karena itu, amat zalimlah seorang pejabat yang memperkaya dirinya dari harta masyarakat tersebut, sehingga pantas mereka dimasukan dalam kelompok orang - orang yang memerangi Allah

\footnotetext{
${ }^{19}$ Mujar Ibnu Syarif dan Khamami Zada, Fiqh Siyasah(Doktrin dan Pemikiran Politik Islam,...h.181
} 
Wery Gusmansyah:

Pemberhentian Kepala Daerah Karena Melakukan Tindak Pidana Korupsi Menurut Undang-Undang Hukum Islam

Swt dan Rasulullah Saw dan membuat kerusakan dimuka bumi. ${ }^{20}$

Penanganan masalah pejabat yang korupsi di dalam ketatanegaraan islam diserahkan kepadala lembaga mazhalim. Majelis Mazhalimlah yang berwenang memberhentikan siapa pun pejabat pemerintah (hakim) dan pegawai negeri sebagaimana dia juga berwenang memberhentikan khalifah. ${ }^{21}$ Akan tetapi, mahkamah mazhalim tidak memiliki wewenang memberhentikan para pejabat pemerintahan (hukkam) dalam kapasitasnya sebagai wakil khalifah. Sebab, majelis tersebut bukan wakil khalifah dalam pengangkatan dan pemberhentian melainkan mewakilinya dalam menjatuhkan keputusan terhadap perkara kezhaliman para pejabat atau kepala daerah di daerahnya.

Contoh kasus dalam upaya menuntut impeacment terhadap Aliyu Bab (1258-1296 H/1842-1859 M), Sultan Sokoto di Afrika Selatan. Dalam kasus ini, enam anggota Majelis alSyura terkemuka menuduh sultan bahwa. Pertama, ia telah banyak mengumpulkan semua pendapatan daripada membagikannya di antara orang-orang Muslim sebagaimana dituntut oleh syariat. Kedua, ia telah membiarkan

${ }^{20}$ Sumarwoto, Hukum Islam Terhadap Tindak Pidana Korupsi, RECHSTAAT Ilmu Hukum Fakultas Hukum UNSA, Vol. 8 no. 1 (Maret, 2014), h.3

${ }^{21}$ Abdul Qadim Zallum, Sistem Pemerintahan Islam (Nidhamul Hukmi Fil Islam)..., h.249 tembok Sokoto dan Masjid Shehu (pendiri Khilafah Sokoto) runtuh tanpa diperbaiki. Ketiga, ia tidak pernah ambil dalam jihad. Mereka memutuskana menarik kesetiaan mereka dari Sultan dan bahkan mengajukan dua calon yang berkualifikasi sebagai penggantinya. Sultan yang memegang jabatan tersebut buru-buru ke ibukota, muncul di depan para anggota, dan mempertahankan diri dari tuduhan. Menyetujui bahwa Khalifah telah membebaskan diri dari tuduhan-tuduhan mereka, anggotaanggota Majelis al-Syura pun memperbaiki kesetiaan mereka. ${ }^{22}$

Dari contoh kasus diatas penulis memahami bahwa anggota-anggota Majelis al-Syura mengusulkan pemberhentian Sultan dengan 3 tuduhan salah satunya karena memperkaya diri atau korupsi, akan tetapi tidak terjadi karena Sultan terbebas dari tuduhantuduhan tersebut.

Ketika khalifah/imam/kepala negara melakukan faktor-faktor yang membolehkan pemberhentin maka menurut Taqi al-Din al-Nabhani yang mempunyai wewenang untuk memberi peringatan dan memberhentikan khalifah hanyalah Mahkamah Mazhalim. Usul pemberhentian Khalifah menurutnya dapat berasal dari umat yang

${ }^{22}$ Mujar Ibnu Syarif dan Khamami Zada, Fiqh Siyasah (Doktrin dan Pemikiran Politik Islam), (Jakarta: Erlangga, 2008), h.186-187 
disampaikan ke Mahkamah Mazhalim.

Selain itu, usul pemecatan Khalifah juga dapat berasal dari anggota Majelis alSyura. Selanjutnya usul yang berasal dari anggota Majelis al-Syura itu diinstruksikan kepada Mahkamah Mazhalim untuk diselediki atau pembuktian apakah khalifah benar-benar telah melanggar syari'at, melanggar hukum, melakukan dosa besar, dan tidak lagi memenuhi kualifikasi sebagai Khalifah. $^{23}$

Bila terbukti Majelis al-Syura segera mengadakan sidang istimewa untuk melakukan impeachment. sebelum sidang istimewa untuk melakakukan pemecatan khalifah digelar, khalifah yang akan dipecat itu diberikan waktu 10 hari untuk melakukan pembelaan atas tuduhan-tuduhan yang ditujukan kepadanya. Bila pledoinya ditolak, maka ia segera dipecat bila sekurangkurangnya 2/3 anggota Majelis al-Syura yang hadir dalam sidang istimewa untuk melakukan impeachment khalifah menyetujuinya. $^{24}$

Khalifah yang diberhentikan kedudukannya digantikan oleh wakil khalifah hingga masa jabatan yang ditentukan untuknya berakhir. Tetapi, bila tidak ada wakil khalifah maka yang

${ }^{23}$ Mujar Ibnu Syarif dan Khamami Zada, Fiqh Siyasah(Doktrin dan Pemikiran Politik Islam...h.188

${ }^{24}$ Mujar Ibnu Syarif dan Khamami Zada, Fiqh Siyasah(Doktrin dan Pemikiran Politik Islam...h.189 menggantikan kedudukan khalifah adalah Ketua Majelis Permusyawaratan (Majelis al-Syura) sampai pemilihan untuk mengisi jabatan khalifah yang kosong itu diadakan, dalam masa maksimum tiga hari semenjak tanggal pemberhentian atau wafatnya khalifah yang lama. ${ }^{25}$

Al-Mawardi berpendapat dalam kitabnya Al-Ahkam As suthaniyyah dalam pemberhentian Kepala Daerah perlu diperhatikan beberapa hal. Jika kepala daerah telah mengangkatnya, maka menteri tawfidh mempunyai hak untuk memperlihatkan dan memeriksa hasil kerjanya, tetapi ia tidak mempunyai hak untuk memberhentikannya atau pun memindahkannya dari wilayah ke wilayah lain. Sedangkan jika menteri itu sendiri yang mengangkat kepala daerah maka ada dua kemungkinan yaitu :

1. Menteri mengangkat Kepala Daerah tersebut dengan seizin Kepala Negara. Dalam hal ini, menteri tidak boleh memberhentikan atau pun memindahkannya dari tugas ke tugas lainnya kecuali setelah mendapat izin Kepala Negara dan turun instruksi darinya. Jika menteri berhenti maka Kepala Daerah tidak turut berhenti.

2. Menteri mengangkatnya dengan inisiatif sendiri dan Kepala Daerah

${ }^{25}$ Al-Nabhani, Sistem Pemeritahan Islam dan Realita Doktrin Sejarah Empiri..., h.115 
Wery Gusmansyah:

Pemberhentian Kepala Daerah Karena Melakukan Tindak Pidana Korupsi Menurut Undang-Undang Hukum Islam

tersebut bertugas sebagai perwakilan wewenangnya. Menteri dapat dengan sendirinya memberhentikannya dan juga menggantikannya dengan yang lain sesuai dengan ijtihadnya siapa yang sesuai untuk menduduki jabatan tersebut. Maka pada saat menteri tersebut berhenti, Kepala Daerah juga berhenti kecuali jika Kepala Negara mengesahkan jabatannya, sehingga hal itu menjadi pembaharuan jabatannya. ${ }^{26}$

Jika Kepala Daerah diangkat oleh Kepala Negara, Kepala Daerah itu tidak diberhentikan dengan meninggalnya Kepala Negara yang mengangkatnya karena pengangkatan yang dilakukan oleh khalifah atas nama kaum muslimin, sedangkan jika diangkat oleh menteri maka Kepala Daerah harus diberhentikan ketika sang menteri meninggal dunia sebab pengangkatan Kepala Daerah tersebut berdasarkan inisiatif dirinya sendiri. ${ }^{27}$

Al-Din al-Nabbani berpendapat bahwa pemberhentian kepala daerah tergantung kepada kepala negara. Jika kepala negara berpendapat harus diberhentikan, maka kepala daerah

\footnotetext{
${ }^{26}$ Imam Al-Mawardi,Hukum Tata Negara dan Kepemimpinan Dalam Takaran Islam Penerjemah Abdul Hayyie al-Khattani dan Kamluddin Nurdin, (Jakarta: Gema Insani, 2000), h.64-65

${ }^{27}$ Imam Al-Mawardi,Hukum Tata Negara dan Kepemimpinan Dalam Takaran Islam Penerjemah Abdul Hayyie al-Khattani dan Kamluddin Nurdin,...h.66-67. 40
}

tersebut akan diberhentikan atau jika rakyat dan/atau majelis umat di daerahnya menunjukan sikap benci dan tidak ridha terhadap kepala daaerah tersebut maka dia harus diberhentikan. Sedangkan yang berhak memberhentikannya adalah kepala negara. Hal tersebut disebabkan Rasulullah pernah memberhentikan Mu'adz bin Jabal dari Yaman tanpa alasan apa pun. Rasulullah juga pernah memeberhentikan 'Ila al-Hadhrami yang menjadi amil beliau di Bahrain, hanya karena Rasul mendapat pengaduan tentang 'ila dari utusan Abdul Qais.

Umar bin Khatab juga memberhentikan seorang Kepala daerah dengan alasan tertentu. Beliau juga memberhentikan Ziyad bin Abi Sufyan dengan tanpa alasan. Kemudian pernah memberhentikan Sa'ad bin Abi Waqqash dengan alasan mendapat pengaduan dari orang-orang tentang dirinya. Khalifah berkata "aku memberhentikannnya bukan karena ia lemah, bukan juga karena ia berkhianat". Semua menunjukkan bahwa kepala negara berhak berhak memberhentikan seorang kepala daerah kapan saja. Dia juga berhak memberhentikan saat ada pengaduan dari penduduk daerah yang di 
pimpin oleh kepala daerah tersebut. ${ }^{28}$ Menurut Al-Baqillani seorang ahli teologi mazhab asy'ari sebagaimana dikutip oleh Muntaz Ahmad dalam buku masalah-masalah teori politik Islam menyebutkan bahwa kepala daerah adalah seseorang yang diberi kuasa dari wakil rakyat, dan rakyat harus mendukung dan mengingatkan akan kewajiban-kewajiban dan tanggung jawabnya serta memaksanya untuk mengikuti jalan yang benar. Apabila ia telah melakukan kesalahan, maka rakyat boleh menggantinya dengan orang lain sebagai upaya terakhir. Al-biqallani pada dasarnya menolak pembatalan kontak, meskipun kepala daerah memenuhi semua persyaratan untuk jabatannya. Tetapi dibagian lain, Al-Baqillani menyebutkan bahwa kepala darah boleh diberhentikan apabila ingkar, melalaikan shalat dan mengajak orang lain untuk melakukan hal yang sama atau jika menjadi cacat jasmani, penyelewengan dan tingkah laku yang tidak bermoral, ketidak adilan, dan kelalaian terhadap hukum-hukum Islam. Hal tersebut membenarkan alasan untuk pemecatan terhadap kepala daerah. ${ }^{29}$

${ }^{28}$ Abdul Qadim Zallum,Sistem Pemerintahan Islam(Nidhamul Hukmi Fil Islam),(Bangil : AlIzzah,2002),h.234-235

${ }^{29}$ Muntaz Ahmad,Masalah-masalah Teori Politik Islam penerjemah Ena Hadi cet III,(Bandung :Mizan,1996),h.79-103
Menurut

Al-Baghdadi

sebagaimana dikutip oleh J Suyuti Pulungan menjelaskan bahwa seorang kepala daerah yang tanpa cacat dan tindakannya tidak bertentangan dengan syari'at umat wajib didukung dan menaatinya. Tapi apabila ia menyimpang dari ketetapan syari'at umat masyarakat harus memilih diantara dua tindakan yaitu mengembalikannya ke jalan yang benar atau mencopot jabatannya dan menggantikannya dengan orang lain. Menurut Al-Juwaini, kepala daerah yang diangkat melalui dengan pemilihan maka tidak boleh memberhentikannya kecuali ada suatu peristiwa atau perubahan sesuatu dari dalam dirinya seperti Fasiq dan Fajir.

Dari uraian diatas disimpulkan bahwa mekanisme pemberhentian kepala daerah secara teoritis figh siyasah bisa saja terjadi, apabila kepala daerah tersebut sudah menyimpang dari syariat, tidak adil, tidak memnuhi syarat lagi menjadi kepala daerah dan kepala Negara pun meyetujui pemberhentian kepala daerah tersebut. Jika dikaitkan dengan fenomema saat ini, Kepala daerah yang melakukan tindak pidana korupsi juga termasuk telah menyimpang dari syari'at yaitu berbuat fasiq dan fajir. Ayat dalam Al-Qur'an yang berkaitan dengan Korupsi yaitu Q.S al-Baqarah ayat 188 :

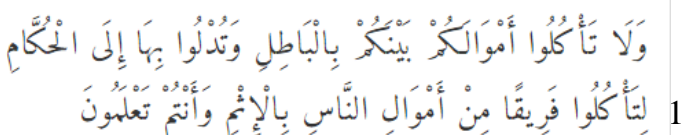


Wery Gusmansyah: Pemberhentian Kepala Daerah Karena Melakukan Tindak Pidana Korupsi Menurut Undang-Undang Hukum Islam

artinya :

Dan janganlah sebagian kamu memakan harta sebagian yang lain diantara kamu dengan jalamn yang bathil dan (janganlah) kamu membawa (urusan)harta itu kepada hakim, supaya kamu dapat memakan sebagian daripada harta benda orang lain itu dengan (jlan berbuat) dosa, padahal kamu mengetahui.

Dalam hadist disebutkan hal yang berkaitan dengan korupsi. Nabi menyatakan yang artinya "Dari Abdullah bin Umar r.a berkata : "Rasulullah melaknat bagi penyuap dan yang menerima suap." (HR.al-khasanah dishahihkan oleh at-Tirmidzi)". 30

Pembahasan proses atau pun prosedur pemberhentian kepala daerah yang melakukan tindak pidana korupsi dalam hukum Islam tidak disebutkan secara rinci baik dalam Al-Qur'an maupun sunnah. Akan tetapi para teoritis fiiqh siyasah hanya menjelaskan penyebab atau faktor-faktor yang bisa menyebabkan pemberhentian kepala daerah. Menurut penulis mekanisme yang relevan terkait pemberhentian kepala daerah yang melakukan tindak

${ }^{30}$ Harun al-Rasyid,Fikih Korupsi;Analisis Politik Uang di Indonesia dalam perspektif Maqhashid alSyari'ah,(Jakarta :Prenamedia Group,2016) h.221 pidana korupsi bisa diqiyaskan dengan proses impeachment khalifah/imam/kepala negara. Dimana Perkara tindak pidana korupsi yang berwenang mengadili adalah Mahkaamah Mazhalim. Qadhi Mazhalim berwenang memberhentikan siapapun di antara pejabat pemerintah (hakim) dan pegawai negeri sebagaimana dia juga memiliki wewenang untuk memberhentikan khalifah. Yang dimaksud dengan pejabat perintahahan yaitu pejabat yang didangkat dengan akad penyerahan (aqdut taqliid) oleh Khalifah seperti yang dikemukakan Imam Al-mawardi. Sehinnga dapat disimpulkan bahwa Kepala Daerah yang melakukan tindak pidana korupsi diadili di Mahkamah Mazhalim untuk menjatuhkan keputusan terhadap perkara tersebut (putusan/vonis). Selanjutnya yang berwenang memberhentikan Kepala Daerah tersebut adalah khalifah.

3. Persamaan dan Perbedaan Mekanisme Pemberhentian Kepala Daerah Karena Melakukan Tindak Pidana Korupsi

Kepala Daerah yang melakukan tindak pidana korupsi harus menerima akibat hukum. Adapun persamaan dan perbedaan dalam mekanisme pemberhentian Kepala Daerah yang melakukan tindak pidana korupsi, sebagai berikut: 
1. Bagi Kepala daerah yang terlibat melakukan tindak pidana korupsi, dalam proses pemberhentian tersebut tanpa di usulkan DPRD. Penyelidikan, Penyidikan dan Penuntutan oleh

KPK/Kepolisian/Kejaksaan.

Kemudian diadili langsung oleh pengadilan Tipikor. Saat berkas telah dilimpahkan ke pengadilan untuk dituntut, diperiksa dan diadili maka akan dilakukan pemberhentian sementara. Pemberehentian sementara dilakukan presiden untuk gubernur dan/atau wakil gubernur. sedangkan untuk bupati dan/atau wakil bupati atau walikota dan/atau wakil walikota dilakukan oleh menteri dalam negeri. Sedangkan perspektif siyasah syar'iyyah, proses pemberhentian Pemimpin/Khalifah/imam/Kepala Negara/Kepala Daerah yang telibat melakukan tindak pidana korupsi diadili di Mahkamah Mazhalim, baik melalui usul dari rakyat langsung atau anggota Majelis Syura.

2. Dalam Hukum Positif sebelum mendapat putusan yang tetap dari pengadilan diberlakukan pemberhentian sementara kepada kepala daerah yang sedang didakwa. Pemberhentian sementara tersebut berfungsi untuk menghormati dan menjunjung tinggi asas presumption of innocent yang menyatakan, setiap orang yang disangka, ditangkap, ditahan, dituntut, dan/atau dihadapkan di depan pengadilan wajib dianggap tidak bersalah sebelum ada putusan pengadilan yang menyatakan kesalahannya dan telah memperoleh kekuatan hukum tetap. Sedangkan dalam siyasah Sya'iyyah tidak menyebutkkan "pemberhentian sementara".

3. setelah putusan pengadilan ditetapkan, jika kepala daerah tersebut tidak terbukti bersalah maka paling lambat 30 hari sejak putusan maka Presiden mengaktifkan kembali Gubernur dan/atau Wakil Gubernur yang bersangkutan dan Menteri mengaktifkan kembali Bupati dan/atau Wakil Bupati dan Walikota dan/atau Wakil Walikota. Apabila terbukti bersalah, diberi waktu tenggang 7 hari sejak putusan untuk mengajukan permohonan banding ke Pengadilan Tinggi. Sedangkan dalam siyasah Syar'iyyah setelah putusan maka pejabat yang bersangkutan diberi waktu 10 hari untuk melakukan pembelaan atas tuduhan-tuduhan yang ditujukan kepadanya. Bila pledoinya ditolak, maka ia segera dipecat bila sekurang-kurangnya 2/3 anggota Majelis al-Syura yang hadir 
Wery Gusmansyah:

Pemberhentian Kepala Daerah Karena Melakukan Tindak Pidana Korupsi Menurut Undang-Undang Hukum Islam

dalam sidang istimewa untuk melakukan pemberhentian.

4. Presiden memberhentikan gubernur dan/atau wakil gubernur dan Menteri memberhentikan Bupati dan/atau Wakil Bupati dan Walikota dan/atau Wakil Walikota. Sedangkan dalam siyasah syar'iyyah yang berhak memberhentikan Kepala daerah yaitu Khalifah jika dia diangkat dengan akad Penyerahahan (aqdut taqliid).

\section{Penutup}

1. Dalam Undang-Undang menjelaskan bahwa bagi kepala daerah yang terlibat melakukan tindak pidana korupsi, dalam proses pemberhentian tersebut tanpa di usulkan DPRD.

2. Pemberhentian Amir/Wali/Kepala Daerah yang melakukan tindak pidana korupsi dalam hukum Islam tidak disebutkan secara rinci baik dalam Al-Qur'an maupun Sunnah. Akan tetapi para teoritis fiigh siyasah hanya menjelaskan penyebab atau faktor-faktor yang bisa menyebabkan pemberhentian kepala daerah.

3. Dalam Hukum Positif yaitu Pengadilan Tindak Pidana Korupsi sedangkan Hukum Islam yaitu Mahkamah Mazhalim.

Presiden/Khalifah berwenang dalam memberhentikan Kepala Daerah, akan tetapi dalam hukum positif hanya Gubernur dan/atau Wakil Gubernur saja sedangkan Bupati dan Walikota diberhentikan oleh Mendagri.

\section{Pustaka Acuan}

Abdul Qadim Zallum,Sistem Pemerintahan Islam(Nidhamul Hukmi Fil Islam),(Bangil : Al-Izzah,2002)

Andi Mustari Pide, Otonomi Daerah Dan Kepala Daerah Memasuki Abad XXI, (Jakarta: Radar Raya Pratama, 1999)

Azyumardi Azra, kajian Termasuk Al-Qur'an Tentang Kemasyarakatan, (Bandung: Angkatan, 2008).

Haji Elwi Daniel, Korupsi : Konsep,Tindak

Pidana dan Pemberatasannya,

(Jakarta: Rajawali Pers, 2012).

Hamdan Zoelva, Impeachment Presiden Alasan Tindak Pidana Pemberhentian Presiden Menurut UU 1945, (Jakarta: Sinar Grafika, 2011).

Harun al-Rasyid,Fikih Korupsi;Analisis Politik Uang di Indonesia dalam perspektif Maqhashid al-Syari'ah,(Jakarta :Prenamedia Group,2016)

Imam Al-Mawardi,Al-Ahkam AsSulthaniyyyah,wal-wilaayaatud-diniyh Terjemahan Abdul hayie,dkk, Hukum Tata Negara dan Kepemimpinan, (Jakarta: Darul Falah,2007).

Mahfud MD, Membangun Politik Hukum Menegakkan Konstitusi, (Jakarta: Rajwali Press, 2012)

Mujar Ibnu Syarif dan Khamami Zada, Fiqh Siyasah(Doktrin dan Pemikiran Politik Islam),(Jakarta : Erlangga, 2008). 
AL-IMARAH: Jurnal Pemerintahan dan Politik Islam

Vol. 3, No. 1, 2018

Muntaz Ahmad,Masalah-masalah Teori

Politik Islam penerjemah Ena Hadi cet

III,(Bandung :Mizan,1996).

Robert Klitgaard, Membassmi Korupsi ,Cet-.II,

(Jakarta: Yayasan Obor Indonesia ,2001), h.31.

Siswanto Sunarno, Hukum Pemerintahan Daerah di Indonesia, (Jakarta: Sinar Grafika, 2006)

Sumarwoto, Hukum Islam Terhadap Tindak Pidana Korupsi, RECHSTAAT Ilmu Hukum Fakultas Hukum UNSA, Vol. 8 no. 1 (Maret, 2014).

Suyuti Pulungan, Fiqh Siyasah:ajaran, sejarah, dan pemikiran, (Jakarta: PT Raja Grafindo Persada, 1994).

Taqiyuddi An Nabhani, Sistem Pemrintahan Islam:Dokttrin Sejarah dan Realitas Empiris)

Undang-Undang RI Nomor 31 Tahun 1999 Pemberantasan Tindak Pidana Korupsi 